\title{
Margaret McCartney: Uncertain science in soundbites
}

\author{
Margaret McCartney, general practitioner
}

Glasgow

Evidence and public policy mix like Baileys and diet cola. For months I've bravely wrestled with my gin choice (Harris or Hendrick's? Blackwoods or the Botanist?)—despite Public Health England's advice to the nation that all regular alcohol is bad. ${ }^{1}$

As a collector of gins and a peruser of tonics I've maintained my cheer, which was threatened when the chief medical officer for England informed a select committee, "Do as I do when I reach for my glass of wine-think, 'Do I want the glass of wine or do I want to raise my own risk of breast cancer?",2

When I drink I consider many things: how lovely life is, how witty my jokes are, and why it's a good idea to leave cleaning up until morning. This is, clearly, why I'm not chief medical officer. But, thinking soberly, is all alcohol harmful?

The Department of Health says yes: "Drinking any level of alcohol regularly carries a health risk for anyone." Yet expert advice from Sheffield described J shaped curves for mortality versus alcohol intake: at low intake, the risks seem outweighed by benefits. ${ }^{3}$ Caveats and uncertainty exist, and benefits of drinking small amounts may be overestimated. But a conflict remains between an easy message and a correct one.

"People have a right to accurate information and clear advice about alcohol and its health risks," say the new guidelines. ${ }^{4}$ This is true. But the recommendations have distilled complexity into soundbite snacks - high on instant satisfaction but poor on long term nutritional value. Since the news reached the media, alcohol is terrible and cancer is everywhere, with little explanation of uncertainty and caveat.

And now, yet more press delight over public health, with a rumpus over diet. "Fat is our friend," and "You can't outrun a bad diet," we hear-but evidence shows that exercise in addition to diet does result in greater weight loss. ${ }^{6}$ The evidence around high fat, low carbohydrate diets contains multiple uncertainties and can't reasonably promise to "reverse obesity and type 2 diabetes," as proponents claim. A recent systematic review found otherwise. ${ }^{7}$
But this doesn't mean that I believe the current guidelines on diet to be highly evidence based: to reduce the large uncertainties will require multilateral effort. This won't happen while certainty is promoted despite fuzzy science.

The most interesting statement on alcohol from Public Health England was that it found "little evidence regarding the impact of any guidelines in changing health behaviours."4 To which I reply: what, then, are the harms of having a debate about false certainty in public? Pass the gin.

Competing interests: See www.bmj.com/about-bmj/freelancecontributors/margaret-mccartney.

Provenance and peer review: Commissioned; not externally peer reviewed.

1 Department of Health. New guidelines show increased risk of cancer. 8 Jan 2016. https: //www.gov.uk/government/news/new-alcohol-guidelines-show-increased-risk-of-cancer. 2 BBC News. England's medical chief gives stark alcohol warning. 2 Feb 2016. www.bbc. co.uk/news/health-35471958.

3 Holmes J, Angus C, Buykx P, et al. Mortality and morbidity risks from alcohol consumption in the UK: analyses using the Sheffield Alcohol Policy Model (v.2.7) to inform the UK chief medical officers' review of the UK lower risk drinking guidelines-final report. 8 Jan 2016. https://www.shef.ac.uk/polopoly_fs/1.5386711/file/Drinking_Guidelines_Final_Report_ Published.pdf.

4 Department of Health. Alcohol guidelines review: report from the guidelines development group of the UK chief medical officers. Jan 2016. https://www.gov.uk/government/uploads/ system/uploads/attachment_data/file/489797/CMO_Alcohol_Report.pdf.

5 National Obesity Forum, Public Health Collaboration. Eat fat, cut the carbs and avoid snacking to reverse obesity and type 2 diabetes. 23 May 2016. https://phcuk.org/wpcontent/uploads/2016/05/Eat-Fat-Cut-The-Carbs-and-Avoid-Snacking-To-Reverse-Obesityand-Type-2-Diabetes-National-Obesity-Forum-Public-Health-Collaboration.pdf.

6 Johns DJ, Hartmann-Boyce J, Jebb SA, Aveyard P. Behavioural Weight Management Review Group. Diet or exercise interventions vs combined behavioral weight management programs: a systematic review and meta-analysis of direct comparisons. J Acad Nutr Diet 2014;114:1557-68. doi:10.1016/j.jand.2014.07.005 pmid:25257365.

7 Tobias DK, Chen M, Manson JE, Ludwig DS, Willett W, Hu FB. Effect of low-fat diet interventions versus other diet interventions on long-term weight change in adults: a systematic review and meta-analysis. Lancet Diabetes Endocrinol 2015;3:968-79. doi:10. 1016/S2213-8587(15)00367-8 pmid:26527511.

Published by the BMJ Publishing Group Limited. For permission to use (where not already granted under a licence) please go to http://group.bmj.com/group/rights-licensing/ permissions 